\title{
HISTORY OF WOMEN'S ACTIVITIES IN LIGHT INDUSTRY OF UZBEKISTAN
}

\author{
Fazilat Akramova
}

Lecturer Of The Department "History Of Uzbekistan", National University Of Uzbekistan, Faculty Of History, Uzbekistan

\section{ABSTRACT}

This article provides a detailed overview of the role and importance of women's participation in the light industry of Uzbekistan. The history of human society is unthinkable without light industry. With the development of a person, his needs grew, and in particular his needs for clothes, shoes, fabrics. The textile, sewing, leather and fur and footwear industries developed. The impetus for industrialization and the development of capitalism was the development of textile production.

KEYWORDS: - Womens, industry, textile, Second World War, Soviet Union, Uzbekistan

\section{INTRODUCTION}

From the earliest days of Soviet rule, the party pursued a "Leninist national policy" and fought hard for the liberation of the women of the peoples of Soviet Turkestan, including Uzbek women. The real goal is clear to everyone.

During the Second World War, the light industry of the USSR suffered heavy damage, many light industry enterprises were destroyed. Nevertheless, even during the war, light industry was able to fully provide Soviet soldiers with uniforms, shoes and other items of clothing.

In the post-war years, there was a rapid recovery and development of the industry. In 1950, output amounted to $112 \%$ of the 1940 volume. In addition, the technical level of many enterprises turned out to be much higher than the pre-war level due to the mechanization and automation of production, the commissioning of new capacities and thanks to the achievements of scientific and technological progress. The USSR became one of the world leaders in the light industry. The products have been successfully exported to other countries. Also, the Soviet Union ranked first in the world in the production of footwear ${ }^{1}$.

In the years following the Second World War, women made an invaluable contribution to the restoration of the country's economy, the complete and decisive completion of the building of socialism.

The issues of training industrial cadres of workers and specialists in the country, including in Uzbekistan, the growth of their material wellbeing, cultural and technical level and creative activity at various stages of the development of Soviet society receive more and more comprehensive coverage in Soviet historical

\footnotetext{
${ }^{1}$ История легкой промышленности // https://ria.ru/20170717/1498532225.html Дата обращения: 16.06.2020.
} 
CURRENT RESEARCH JOURNAL OF HISTORY 2(6): 30-33, June 2021

DOI: https://doi.org/10.37547/history-crjh-02-06-07

ISSN 2767-472X

(C)2021 Master Journals

\section{Crossref do) 81 Google}

Accepted 14 ${ }^{\text {th }}$ June, 2021 \& Published 19th June, 2021

literature.

This is evidenced by the historiographic review of the literature on the working class, on industrial development, given in the collective works, monographs and articles of M.A. Akhunova, B.V. Lunin, G.I. Zheltova, I.E. Vorozheikin, E.E. Beilina and other scientists ${ }^{2}$.

Thanks to the successful implementation of the first post-war five-year plans, Soviet Uzbekistan in the mid-1950s was a republic with a diversified industry and mechanized agriculture. By this time, the increasing importance in the national economy of the country began to be occupied by the industry of Uzbekistan, especially such industries as the chemical industry, mechanical engineering, and nonferrous metallurgy. Uzbekistan became the main producer and supplier of agricultural machinery for processing cotton crops for all cotton regions of the USSR. The production of mineral fertilizers has reached the volume, which made it possible to supply part of the products to the neighboring fraternal republics. The electrical engineering industry, the production of technological equipment and machinery for many sectors of the national economy have developed significantly ${ }^{3}$.

2 Ахунова М.А., Лунин Б.В. История исторической науки в Узбекистане. Краткий очерк.- Т.:"Фан", 1970; Желтова Г.И., Исламджанова М.Г. Рабочий класс Узбекистана в освещении советской историографии. В журн. "Общественные науки в Узбекистане", 1972, № б; Ворожейкия И.Е. Очерк историографии рабочего класса СССР.- М.:Политиздат,1975; Ежов В.А. Рабочий класс СССР в современной советской историографии. В кн.: Рабочий класс в мировом революционном процессе".- М.: Наука, 1975; Ворожей-дин И.Е., Сенявский С.Л. Рабочий класс - ведущая сила советского общества (Вопросы методологии и историографии).-М.: Мысль, 1977; д др.

3 Усманов А.У. Подготовка промышленных кадров Узбекистана и рост их творческой активности (1956-
Of course, in the period after 1965. the state of affairs with the training of personnel in general, in particular for industry, has improved significantly. During the period under study, there were still significant shortcomings and problems in this important area. Due to the weak development of the network of vocational schools, the overwhelming majority of young workers were trained directly in production. Few trained and highly qualified specialists. This was one of the reasons for the low level of engineering, economic and planning work at many enterprises; in an insufficient number of specialists trained for a number of rapidly developing industries, in particular, for nonferrous metallurgy, electrical, gas, petrochemical ${ }^{4}$.

Much work on the training and advanced training of agricultural personnel in the country, including Uzbekistan, was done in the years of the ninth five-year plan (I97I-I975).

There was a significant disproportion between the continuously increasing equipment of farms with machinery and the machine-operator personnel capable of operating it. For example, by the beginning of 1971, the republic lacked more than 40 thousand tractor drivers and many other machine operators, and hence the low shift ratio, insufficient use of equipment. The available cadres were unevenly distributed over the regions and districts of the UzSSR. The scale and profile of training new personnel in vocational schools, higher and secondary specialized educational institutions did not properly correspond to the real needs of cotton growing, animal husbandry and other sectors of

1965 гг.): Авторефер. дисс. ... канд. истор. наук. - М., 1984. - C. 22.

4 Усманов А.У. Подготовка промышленных кадров Узбекистана и рост их творческой активности (19561965 гг.): Авторефер. дисс. ... канд. истор. наук. - М., 1984. - C. 24. 
CURRENT RESEARCH JOURNAL OF HISTORY 2(6): 30-33, June 2021

DOI: https://doi.org/10.37547/history-crjh-02-06-07

ISSN 2767-472X

(C)2021 Master Journals

\section{Crossref do) 81 Google}

Accepted 14 ${ }^{\text {th }}$ June, 2021 \& Published 19thJune, 2021

agriculture. The proportion of female machine operators was low. In order to eliminate these and other shortcomings, the party, Soviet, economic and public organizations of the republic, guided by the decisions of the party and the government, have done a lot during the ninth five-year plan to expand and improve the entire system of training, retraining and advanced training of agricultural personnel - leaders, specialists, workers of mass trades and especially machine operators ${ }^{5}$.

During the ninth five-year plan, which became an important stage in the improvement of the society of mature socialism, the training of agricultural personnel in the country rose to a new level. Various forms of training and advanced training of workers were deployed, measures for the creation of rural vocational schools took on a large scale, state farmstechnical schools and other forms of education arose. Notable successes have been achieved in the training of female machine operators, workers of mass trades ${ }^{6}$.

Coaching became widespread in the republic in 1975. This year, 50,000 coaches took care of 156,000 boys and girls. In 1980, 110,000 coaches were involved in the vocational training and education of 230,000 young workers. In 1975, the Tashkent Textile Combine launched a remarkable initiative under the motto "Let the young worker-coach achieve his goal.". Wellknown weaver, A.S. Verzilina was the initiator of this patriotic movement. She herself taught the

\footnotetext{
5 Зохидов Т.Т. «Подготовка и повышение квалификации сельскохозяйственных кадров в Узбекистане в годы девятой пятилетки (1971-1975 гг.): Авторефер. дисс. ... канд. истор. наук. - М., 1984. - С. 23

${ }^{6}$ Зохидов Т.Т. «Подготовка и повышение квалификации сельскохозяйственных кадров в Узбекистане в годы девятой пятилетки (1971-1975 гг.): Авторефер. дисс. ... канд. истор. наук. - М., 1984. - С. 11
}

craft to many young women. His students S. Fashutdinova and A. Molodovaya, graduates of vocational schools, completed their assignments in the first year of the fifteenth year. A.S. Verzilina herself has completed two personal five-year careers in five years, delivering only first-class products ${ }^{7}$. When we talk about the activities of women in the light industry of Uzbekistan, we all know that there are positive and negative aspects.

In the 1990s, there was a significant decline in the production of light industry products. The opening of the market led to a massive influx of cheap, low-quality imported goods. Light industry products turned out to be uncompetitive in comparison with foreign manufacturers, especially with China.

The collapse of the USSR complicated the supply of raw materials from the former Soviet republics, especially for the cotton industry, since cotton is not grown in Russia due to its natural and climatic conditions. The share of light industry in GNP began to decline.

Today, when we talk about Uzbekistan, our country is recognized as a modern state with rapidly developing industry and growing economic power and potential. This is due to the fact that during the years of independence, all areas of industry in our country, especially hightech industries, are constantly developing.

It is especially gratifying that such gratifying results, achieved in a very short period of history, are highly valued internationally. Let's not go too far, according to a recent World Bank ranking of countries on economic development, Uzbekistan ranks 66th out of 190 countries in terms of GDP calculated on the basis of the purchasing power parity of the national currency. It is clear that in recent years, the

\footnotetext{
${ }^{7}$ Исмоилова Г.У. Ўзбекистонда хотин-қиз ишчи кадрлар тайёрлаш. -Тошкент: Ўзбекистон, 1983 йил. 20-бет.
} 
CURRENT RESEARCH JOURNAL OF HISTORY 2(6): 30-33, June 2021

DOI: https://doi.org/10.37547/history-crjh-02-06-07

ISSN 2767-472X

(C)2021 Master Journals

\section{Crossref do) 81 Google}

Accepted 14 $4^{\text {th }}$ June, 2021 \& Published 19thJune, 2021

country has risen by 6 points on this indicator ${ }^{8}$.

In short, the consistent implementation of wellthought-out reforms in our country ensures not only the rapid development of the light industry, but also the strengthening of our economy. As the president said, "Today we can say without hesitation that Uzbekistan has a rapidly growing modern industrial sector with a historically short-lived one-sided economy, mainly adapted to the supply of raw cotton, and a catastrophic cotton monopoly. It has become a rapidly developing country."

\section{REFERENCES}

1. Ахунова М.А., Лунин Б.В. История исторической науки в Узбекистане. Краткий очерк. - Т.: Фан, 1970.

2. Ворожейкин И.Е., Синявский С.Л. Рабочий класс - ведущая сила советского общества (Вопросы методологии и историографии). -М.: Мысль,1977.

3. Ворожейкин И.Е. Очерк историографии рабочего класса СССР.- М.: Политиздат, 1975.

4. Ежов В.А. Рабочий класс СССР в современной советской историографии. - М.: Наука, 1975.

5. Желтова Г.И., Исламджанова М.Г. Рабочий класс Узбекистана в освещении советской историографии // Общественные науки в Узбекистане, 1972, № 6.

6. Зохидов Т.Т. Подготовка и повышение квалификации сельскохозяйственных кадров в Узбекистане в годы девятой пятилетки (1971-1975 гг.): Авторефер. дисс. ... канд. истор. наук. - М., 1984.

7. Исмоилова Г.У. Ўзбекистонда хотин-қиз ишчи кадрлар тайёрлаш. -Тошкент: Ўзбекистон, 1983.

8. История легкой промышленности // https://ria.ru/20170717/1498532225.ht $\mathrm{ml}$. Дата обращения: 16.06.2020.

9. Усманов А.У. Подготовка промышленных кадров Узбекистана и рост их творческой активности (19561965 гг.): Авторефер. дисс. ... канд. истор. наук. - М., 1984.

10. Ўтбосаров И., Рахмонов С. Енгил саноат: Юксалишнинг жадал суръатлари // Халқ сўзи online, 2014. 1 ноябр

11. Ozodbek, N., Tolipov, F., \& Yunusova, X. (2019). Historical and ethnographic features of the Uzbek Kurash. International Journal of Recent Technology and Engineering, 8(2 Special Issue 3), 16141616.

8 Ўтбосаров И., Рахмонов С. Енгил саноат: Юксалишнинг жадал суръатлари // Халқ сўзи online, 2014. 1 ноябр 